\title{
Peertechz
}

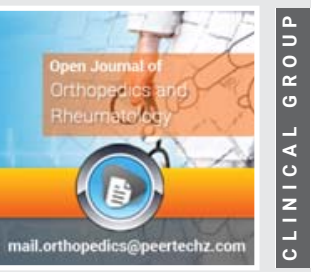

\section{A Young Lady with ANA negative SLE with Secondary Anti Phospholipid Syndrome}

\author{
Richmond Ronald Gomes ${ }^{1 *}$ and Saiful Bahar Khan² \\ ${ }^{1}$ Associate Professor, Internal Medicine, Ad-din Women's Medical College Hospital, Dhaka-1217, \\ Bangladesh
}

${ }^{2}$ Assistant Professor, Nephrology, Ad-din Women's Medical College Hospital, Dhaka-1217, Bangladesh
Received: 27 August, 2020

Accepted: 05 September, 2020

Published: 07 September, 2020

*Corresponding author: Dr. Richmond Ronald Gomes, Associate Professor, Internal Medicine, Ad-din Women's Medical College Hospital, Dhaka-1217, Bangladesh, Tel: 8801819289499;

E-mail: rrichi.dmc.k56@gmail.com

ORCID: http://orcid.org/0000-0002-2511-7972

Keywords: Antinuclear antibody; Anti ribosomal P antibody; Systemic lupus erythematosus; Anti phospholipid syndrome; Auto antibody; Connective tissue disease

https://www.peertechz.com

\section{Check for updates}

\begin{abstract}
Systemic Lupus Erythematosus (SLE) is a chronic, inflammatory, autoimmune, multisystem connective tissue disease characterized by various autoantibodies to nuclear and cytoplasmic antigens and commonly affects the joints and a variety of organs due to an over activation of the body's immune system. There is wide heterogeneity in presentation of SLE patients, including lung, central nervous system, skin, kidney, and hematologic manifestations. The presence of antinuclear antibodies (ANA) in serum is generally considered a decisive diagnostic sign of SLE. However, a small subset of SLE patients who had the typical clinical features of SLE was reported to show persistently negative ANA tests. Our report describes a 24-yr-old female who presented with the clinical manifestations of SLE such as malar rash, photosensitivity, arthritis, oral ulcer and proteinuria. The serum autoantibodies were all negative except anti ribosomal P. She was also positive for lupus anti-coagulant. She was treated with oral prednisolone, hydroxychloroquine with topical tacrolimus and improved significantly. Three months after, repeat ANA and anti-ds DNA showed persistent negativity but lupus anti-coagulant remained positive. This case suggests that ANA may not be required in the pathogenesis of SLE.
\end{abstract}

\section{Introduction}

Systemic lupus erythematosus (SLE) is a complex disease characterized by an autoantibody response to nuclear and cytoplasmic antigens. The autoantibody response is associated with the inflammatory cascades and end-organ damage in the kidney, skin, brain and other organs. Especially in the kidney, immune-complex deposits of autoantibodies have been implicated as major pathogenic mediators [1].

The diagnosis of SLE can be made by fulfilling the revised criteria of the American College of Rheumatology [2]. One of the laboratory hallmarks of SLE is the presence of antinuclear antibodies (ANA) in the serum [3]. On the other hand, a small subset of SLE patients with the typical clinical findings of SLE was reported to have persistently negative ANA test. These patients were designated as ANA-negative SLE and their clinical picture was notable for the high incidence of photosensitive dermatitis and the low incidence of nephritis and neuropsychiatric manifestations [4]. ANA negative SLE was first introduced by Koller et al. with five cases with clinical features similar to SLE [5]. Here we report a young lady presented polyarthritis which was complicated with photosensitive rash and oral ulcer and later diagnosed as ANAnegative SLE.

\section{Case report}

A 24 years old pleasant, unmarried, service holder, muslim lady admitted into Ad din Women's Medical College and Hospital with the complaints of pain in the multiple joints of both upper and lower limbs for last 2 months involving mainly small joints of hands (picture 1) and feet, wrists, ankles. Joint involvement was symmetrical and non-migratory. There was associated inactivity stiffness that lasted for more than an hour and relieved partially with activity and taking analgesics. Joint pain was associated with low grade intermittent fever (max recorded temperature was $100^{\circ} \mathrm{F}$ ), not associated with chills and rigor and subsided after taking anti pyretic. Joint pain was not associated with any redness or increased warmth of the joints. She also denied any low back pain, buttock or groin pain, sole pain or pain over heel. There was also no H/O sexual exposure, urethral discharge or bloody diarrhoea preceding the illness. No red eye, visual impairment, proximal muscle pain or stiffness, papulopustular or acne form or scaly skin lesions 
were present either. There was also no history of dry mouth or dry eye, loss of scalp hair, venous thrombosis, tightening of skins of body, dysphagia, heart burn, altered bowel habit or any history suggestive of Raynaud's phenomenon. She denied any anorexia, night sweat or weight loss. After about one month later she developed painless oral ulcers (picture 2). But there were no genital ulcers.

At the same time she also developed erythematous, raised, painful, non-pruritic photosensitive rashes all over her face sparing the nasolabial folds (pictures 3,4). But there were no bullous lesions or no crusts.
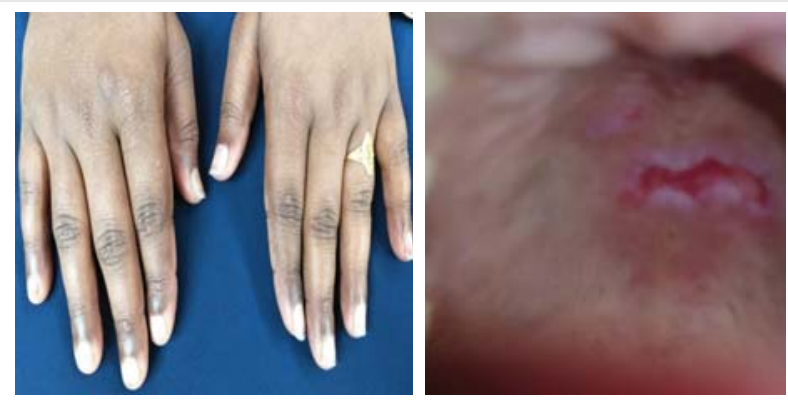

Figure 182: Showing symmetrical arthritis involving MCP and PIP of both hands. Picture 2 showing an erythematous ulcer with irregular margin over hard palate.

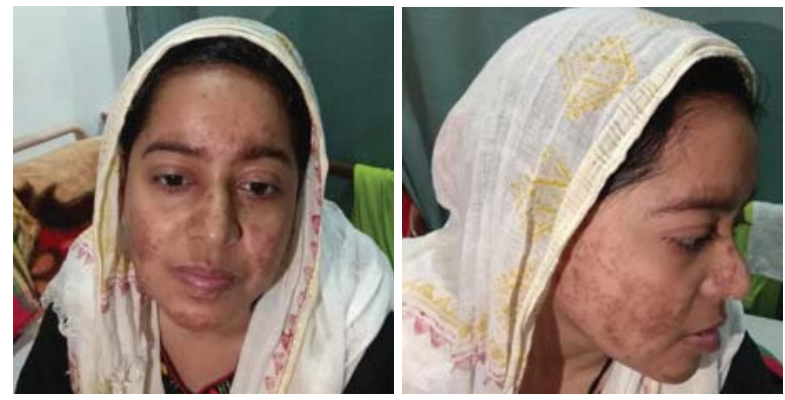

Figure 3\&4: Showing multiple, erythematous, raised rashes with no color change or no crusting all over the face sparing the nasolabial folds.

On further query, she stated that her paternal aunt had SLE. She had no significant drug history prior the illness except she took ceftriaxone for 7 days before admission. Her menstrual history was also noncontributory. She had neither any sexual promiscuity nor had any history of tuberculosis or any contact with the patient with active tuberculosis. On examination she was ill looking, febrile (temperature $100^{\circ} \mathrm{F}$ ) with stable vitals. She was moderately anemic but non-icteric and non-cyanosed. There were erythematous, raised, tender rashes over both cheeks, forehead (sparing naso labial fold), there were some rashes over dorsum of hands and feet too. Skin was not thinned with nobruising or telangiectasia. Eyes including both fundi were normal, lymph nodes were not palpable, and thyroid gland was not enlarged. There was no edema, bony tenderness or any nail or peri-ungual vasculitic changes. On musculoskeletal system examination, GALS screening was done. Gait and spine examination revealed no abnormalities. On upper limb examination, MCP, PIP and wrists of both sides were swollen, tender and there was painful restriction of both active and passive movements of these joints. DIP's were spared. On lower limb examination, ankles and small joints of feet of both sides were swollen, tender and there was painful restriction of both active and passive movements of these joints. There were neither any deformities nor any evidences of sacroilitis or enthesitis. Oral cavity examination revealed painless ulcers with erythematous irregular margin over hard palate, right inner cheek. But there were no organomegaly. There were no evidences for serositis (ascites, pleural or pericardial effusion). Other systemic examination was noncontributory.

On investigation there was microcytic hypochromic anemia of $\mathrm{Hb}-7.92 \mathrm{gm} \%(\mathrm{MCV} 69, \mathrm{MCH}-22)$, ESR $60 \mathrm{~mm}$ in $1^{\text {st }}$ hour, TC-1000/cmm(N-38\%, L-54\%), TPC-1,60000/cmm, CRP. 58.5 $\mathrm{mg} / \mathrm{dl}, \mathrm{PBF}-$ microcytic hypochromic anemia with leucopenia and adequate platelets. Urine R/E revealed; proteinuria $(++)$, RBC- 15-20/HPF (nonmenstruating), granular cast 8-10/HPF. But there were no RBC or tubular cast. S albumin 31 gm/L, UTP1.01 gm/day, ALT- 74 U/L, S. ferritin 4035 ng/L. RFT, RBS, CPK, IgG, DCT, Blood C/S Urine C/S all were noncontributory. On immunological test, ANA, Anti ds DNA, RA factor, Anti CCP all came negative.C4 was low $0.45 \mathrm{~g} / \mathrm{l}$. CXR P/A, Echocardiography, $\mathrm{X}$ - ray of both hands, USG of W/A revealed no abnormalities. Serological investigations for HBV and HCV were negative, VDRL non-reactive, anti cardiolipin antibody was negative but lupus anti-coagulant came positive. As there was still strong clinical suspicion of SLE, ENA profile was done and Po (RPP)60 or anti ribosomal $\mathrm{P}$ antibody came positive.

During hospital stay as patient developed high grade temperature, neutropenic sepsis was suspected and she was treated with combined piperacilin/ tazobactam and aminoglycoside along with isolation and neutropenic diet. 2 units of whole blood were transfused. Systemic steroid (oral prednisolone $1 \mathrm{mg} / \mathrm{kg} /$ day) with DMARD (hydroxychloroquine) was started with topical steroid and tacrolimus ointment .Regular monitoring of both hematological and biochemical parameters were done. On discharge, $\mathrm{Hb} \%-10.1 \mathrm{gm} / \mathrm{L}$,Total count-5200/cmm(PMN- 68\%,L- 30\%),ESR- $34 \mathrm{~mm}$ in $1^{\text {st }} \mathrm{hr}$, TPC $-192000 / \mathrm{cmm}$, CRP- $4.92 \mathrm{mg} / \mathrm{dl}$, Urine R/E- no protein, no casts, no RBC, no WBC, S. Ferritin-243 ng/ml. After three weeks, on OPD follow up, tapering of systemic steroid was started,topical steroid and tacrolimus was stopped. She was advised to use sunscreen regularly. She was also explained about the course of the disease, treatment options, recognition of flares, and pregnancy outcome. Last but not the least,reassurance was given.

After three months, ANA, Anti ds DNA and lupus anti-coagulant were repeated. ANA and anti-ds DNA showed persistent negativity and lupus anti- coagulant remained positive. So she was started low dose aspirin with hydroxychloroquine and tapering dose of steroid.

\section{Discussion}

Systemic lupus erythematosus is a chronic inflammatory autoimmune disease that involves many different organ systems, and this illness exhibits a wide spectrum of clinical manifestations. The diagnosis of SLE depends on the patient's clinical and laboratory abnormalities [2]. Various kinds of 
autoantibodies are present in the sera of SLE patients, and ANA is a diagnostic hallmark for SLE, having a frequency of $95 \%$ or greater in SLE patients [6] and its titre is one of the key diagnostic criteria for SLE. But ANA positivity is not mandatory for the diagnosis [7]. Sero-negativity in lupus patients may be due to technical failure or entrapment of ANA in circulating immune complexes.

The diagnosis of SLE can be made by combining clinical and laboratory findings but there is no criterion available at the moment for early identification of the disease. The 1997 American college of Rheumatology (ACR) criteria [8] and its complimentary criteria; the 2012 systemic lupus international collaborating clinic (SLICC) criteria [9] are designed for classification of SLE but not for the diagnosis. The 2012 SLICC criteria is very complex and it can be used when the ACR criteria cannot classify SLE.

However, several investigators have reported that small groups of patients with the clinical features of SLE have negative tests for ANA. These patients appear to represent $1-5 \%$ of the SLE population. The age of onset and the female predominance are the same for ANA-negative SLE as for ANApositive SLE [10]. ANA-negative SLE patients are known to have a higher prevalence of anti-Ro antibody and cutaneous manifestations, as well as a lower prevalence of both central nervous system and renal involvement [4,11]. Maddison et al. described 66 SLE patients with negative ANA, as was determined by indirect immuno-fluorescence. They found serum antibodies to cytoplasmic components; $62 \%$ of patients had anti-Ro antibody and $27 \%$ had anti-La antibody [4].

One explanation for the ANA-negative finding is technical inaccuracy. McHardy et al. identified 38 adults who had a high DNA-binding capacity, but negative fluorescent ANA testing (with a rat liver substrate), and the clinical diagnosis of SLE was established for these patients [12]. In another study, the previously ANA-negative finding, with using mouse liver substrate, in the sera of patients with SLE or subacute cutaneous lupus erythematosus was found to be anti-Ro antibody positive by performing enzyme-linked immunosorbent assays [13]. Actually, the increasing use of human epithelial (HEp-2) substrate has increased the sensitivity of ANA assays and as a result, the perceived incidence of ANA-negative SLE has decreased $[12,14]$.

Another cause of ANA-negative findings is that ANA is present, but its bound in the form of immune complexes. This has been described in five patients with lupus nephritis whose ANAs, which were primarily reactive with DNA, were not detected in the serum by indirect immunofluorescence until the ANAs were dissociated from circulating immune complexes [15]. Loss of ANA through the kidney in a patient with profuse proteinuria has been reported as another possibility. In that case, the tests for ANA became positive upon clinical recovery [16]. However, most ANA-negative patients have persistently negative tests for ANA after a long follow-up period. Technical factors or prozone effects have been described as the possible reasons for this [17].
SLE is still a disease with significant morbidity and mortality. More recent studies have shown that latest 5 year survival is now nearer $90-95 \%$ and that $70-85 \%$ patients have 10 year survival [18]. In most studies, patient with renal involvement had poor prognosis compared to patient without it.

CRP usually parallels disease activity in inflammatory conditions as it is an acute phase reactant produced by liver. But SLE is an exception. Patient with active SLE display only modestly elevated or even normal CRP level despite active disease. Marked elevation of CRP in SLE patients indicates infection and serositis [19]. Our patient also had modestly elevated CRP during the admission; this may be due to coexisting infection in this patient as she did not have clinical features of serositis.

Steroids such as Prednisolone have dual therapeutic actions in SLE. It has both anti-inflammatory and immunosuppressive actions. It is usually used to treat major organ complications such lupus nephritis and cerebral lupus. Steroid sparing other immunosuppressive agents such as Azathioprine, cyclophosphamide and mycophenolatemofetil should be considered if it is used for long term. When the required daily dose of Prednisolone exceeds $60 \mathrm{mg} / \mathrm{day}$, Intravenous route in the form of Methylprednisolone pulse therapy $(30 \mathrm{mg} / \mathrm{Kg}$, maximum $1 \mathrm{~g} /$ day) should be used. Hydroxychloroquine (HCO) $200-400 \mathrm{mg} /$ day protects against the disease flare and used to treat dermatological and joint manifestations of SLE.

\section{Conclusion}

Our patient fulfilled the ACR criteria $r$ without serologic evidence of SLE at presentation. During the follow-up period, the repeated ANA and anti-dsDNA tests were all negative, irrespective of her improving proteinuria, joint and mucocutaneous symptoms. Our patient may be a very rare case of ANA-negative SLE without seroconversion and this suggests that ANA may not be required in the pathogenesis of SLE. ]. If patient fulfil criteria for SLE despite seronegativity, diagnosis should not be delayed as $5-10 \%$ of SLE patient are seronegative [20]. Auto-antibodies against ribosomal P proteins appear highly specific for SLE found in $10-15 \%$ patients with SLE; therefore, they can be used as diagnostic marker for the disease. Furthermore, association has been described with particular manifestations of lupus, especially with neuropsychiatric, renal, and hepatic involvements. Anti-P positivity and the titer of anti-P antibodies also fluctuate with clinical disease activity [21]. SLE is nearly always diagnosed months to years after the onset of clinical symptoms and as we have previously shown, even longer after the onset of autoantibodies [22] .Antibodies against ribosomal $\mathrm{P}$ frequently develops before clinical SLE diagnosis [23].

\section{References}

1. Bagavant H, Deshmukh US, Gaskin F, Fu SM (2004) Lupus glomerulonephritis revisited 2004: autoimmunity and end-organ damage. Scand J Immunol 60 52-63. Link: https://bit.ly/2Z9vKs5

2. Tan EM, Cohen AS, Fries JF, Masi AT, McShane DJ, et al. (1982) The 1982

Citation: Gomes RR, Khan SB (2020) A Young Lady with ANA negative SLE with Secondary Anti Phospholipid Syndrome. Open J Orthop Rheumatol 5(1): 049-052. DOI: https://dx.doi.org/10.17352/ojor.000026 
revised criteria for the classification of systemic lupus erythematosus. Arthritis Rheum 25: 1271-1277. Link: https://bit.ly/3bsJlj3

3. Enriquez JL, Rajaraman S, Kalia A, Brouhard BH, Travis LB (1988) Isolated antinuclear antibody-negative lupus nephropathy in young children. ChildNephrol Urol 9: 340-346. Link: https://bit.ly/3i5rH7p

4. Maddison PJ, Provost TT, Reichlin M (1981) Serological findings in patients with "ANA-negative" systemic lupus erythematosus. Medicine 60: 87-94. Link: https://bit.ly/2EZDeH6

5. Koller SR, Johnston CL, Moncure CW (1976) Lupus erythematosus cell preparation-antinuclear factor incongruity. A review of diagnostic tests for systemic lupus erythematosus. Am J Clin Pathol 66: 495-505. Link: https://bit.ly/2F4Ffl8

6. Provost TT, Razzaque A, Maddison PJ, Reichlin M (1977) Antibodies to cytoplasmic antigens in lupus erythematosus: serologic marker for systemic disease. Arthritis Rheum 20: 1457-1463. Link: https://bit.ly/2QYflC4

7. Berden JHM (1997) Lupus nephritis. Kidney Int 52: 538-558. Link: https://bit.ly/31YtaGW

8. Hochberg MC (1997) Updating the American College of Rheumatology of revised criteria for the classification of systemic lupus erythematosus. Arthritis Rheum 40: 1725. Link: https://bit.ly/3bC3KSU

9. Petri M, Orbai AM, Alarcons GS, et al. (2012) Derivation and validation of the systemic lupus international clinic collaborating criteria for systemic lupus erythematosus. Arthritis Rheum 64: 2677-2686. Link: https://bit.ly/2FcLpPV

10. Maddison PJ (1982) ANA-negative SLE. Clin Rheum Dis 8: 105-119.

11. Provost TT, Reichlin M (1981) Antinuclear antibody-negative systemic lupus erythematosus: I. anti-Ro (SSA) and anti-La (SSB) antibodies. J Am AcadDermatol 4: 84-89. Link: https://bit.ly/3iODTGE

12. McHardy KC, Horne C, Rennie J (1982) Antinuclear antibody-negative SLE: how common? J ClinPathol 35: 1118-1121. Link: https://bit.ly/2DvpOl

13. Reichlin M (2000) ANA negative systemic erythematosus sera revisited serologically. Lupus 9: 116-119. Link: https://bit.ly/2Z72ySc
14. Kavanaugh A, Tomar R, Reveille J, Solomon DH, Homburger HA (2000) Guidelines for clinical use of the antinuclear antibody test and tests for specific autoantibodies to nuclear antigens. Arch Pathol Lab Med 124: 71-81. Link: https://bit.ly/3250FG9

15. Blomjous FJ, Feltkamp-Vroom TM (1971) Hidden anti-nuclear antibodies in seronegative systemic lupus erythematosus patients and in NZB and (NZB XN2 W) F1 mice. Eur J Immunol 1: 396-398.

16. Persellin RH, Takeuchi A (1980) Antinuclear antibody-negative systemic lupus erythematosus: loss in body fluids. J Rheumatol 7: 547-550. Link: https://bit.ly/359Wv3o

17. Linder E, Miettinen A (1976) Prozone effects in indirect immunofluorescence. ScandJ Immunol 5: 513-519. Link: https://bit.ly/3h3uMU4

18. Trager J, Ward MM (2001) Mortality and causes of death in systematic lupus erythematosus. Curr Opin Rheumatol 13: 345-351. Link: https://bit.ly/357bVVT

19. Honig S, Gorevic P, Weisssmann G (1977) C-reactive protein in systemic lupus erythematous. Arthritis Rheum 20: 1065-1070. Link: https://bit.ly/2DxtX8z

20. Tsakonas E, Joseph L, Esdalie JM, Choquette D, Senécal JL, et al. (1997) A long term study of hydroxychloroquine withdrawal on exacerbations in systemic lupus erythematosus. The Canadian Hydroxychloroquine study Group. Lupus 7: 80-85. Link: https://bit.ly/3jMzk34

21. Kiss E, Shoenfeld $Y(2007)$ Are anti-ribosomal $P$ protein antibodies relevan in systemic lupus erythematosus? Clin Rev Allergy Immunol 32: 37-46. Link: https://bit.ly/3jUsrNn

22. Arbuckle MR, McClain MT, Rubertone MV, Scofield RH, Dennis GJ, et al. (2003) Development of autoantibodies before the clinical onset of systemic lupus erythematosus. N Engl J Med 349: 1526-1533. Link: https://bit.ly/320M7sz

23. Heinlen LD, Ritterhouse LL, McClain MT, Keith MP, Neas BR, et al. (2010) Autoantibodies are Present Before SLE Onset and are Directed Against non-C Terminal Peptides. J Mol Med 88: 719-727.

Discover a bigger Impact and Visibility of your article publication with Peertechz Publications

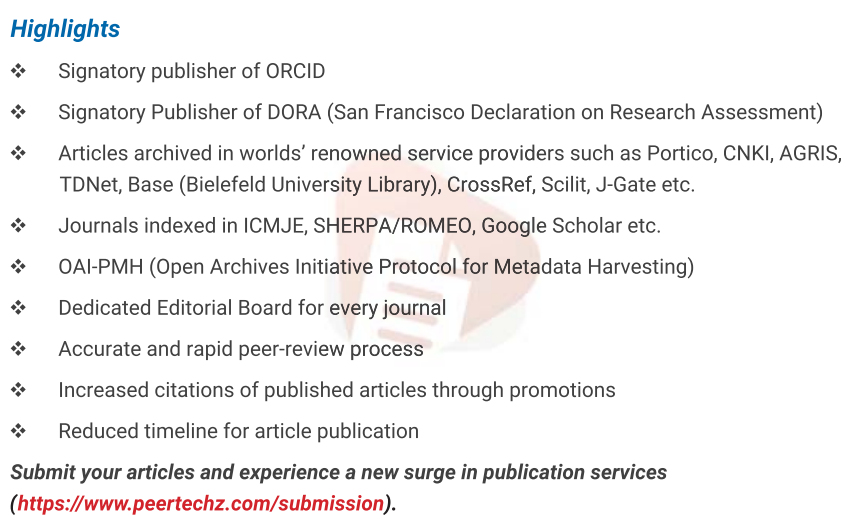

Peertechz journals wishes everlasting success in your every endeavours.

Copyright: @ 2020 Gomes RR, et al. This is an open-access article distributed under the terms of the Creative Commons Attribution License, which permits unrestricted use, distribution, and reproduction in any medium, provided the original author and source are credited.

Citation: Gomes RR, Khan SB (2020) A Young Lady with ANA negative SLE with Secondary Anti Phospholipid Syndrome. Open J Orthop Rheumatol 5(1): 049-052. DOI: https://dx.doi.org/10.17352/ojor.000026 